\title{
Zinc oxide nanocomposites with antitumor activity
}

\author{
Emma Arakelova ${ }^{1^{*}}$, Ashot Khachatryan ${ }^{1}$, Karapet Avjyan $^{1}$, Zoya Farmazyan $^{1}$, \\ Alvard Mirzoyan ${ }^{1}$, Lilia Savchenko', Sedrak Ghazaryan ${ }^{2}$, Flora Arsenyan ${ }^{2}$ \\ ${ }^{1}$ Scientific Research Division, State Engineering University of Armenia, Yerevan, Armenia; \\ *Corresponding Author: emma arakelova@yahoo.com \\ ${ }^{2}$ Laboratory of Syntheses Derivatives amino acids and peptides, Laboratory of toxicology and chemotherapy IFOC (Institute of Fine \\ Organic Chemistry), Yerevan, Armenia
}

Received 25 September 2010; revised 26 October 2010; accepted 30 October 2010.

\begin{abstract}
Zinc oxide nanocomposites in the form of coatings and composite films with antitumor activity were obtained by deposition of $\mathrm{ZnO}$ nanofilms on surfaces of ethyl ether Salicylidene DL-tyrosine (S1) and ethyl ether Salicylidene DL-tyrosine $\mathrm{Cu}$ (II) chelate (S2) by magnetron sputtering of $\mathrm{Zn}$ target. Ethyl ether Salicylidene DL-tyrosine, Cu (II) chelate of ethyl ether salicylidene DL-tyrosine reveal some anticancer properties. Their zinc oxide nanocomposites were obtained in the form of coatings ( $\mathrm{S} 1+\mathrm{ZnO}, \mathrm{S2}+\mathrm{ZnO})$ and composite films presenting a mixture of polyvinyl alcohol (PVA) with S1, S2 (S1 + PVA + ZnO, S2 + PVA + ZnO), for the purpose of increasing anticancer activity. Considerable increase in antitumor activity reveal $\mathrm{ZnO}$ nanocomposites with salicylidene amino acid chelates (as distinct from their ethers) in the form of S2 + ZnO (47\%) and S2 + PVA + ZnO (48\%) in comparison with S2 $(20 \%)$. Structural, spectral properties of the salicylidene amino acids and their $\mathrm{ZnO}$ nanocomposites were studied.
\end{abstract}

Keywords: Zinc Oxide; Nanofilm; Magnetron Sputtering; Nanocomposites; Antitumor Activity

\section{INTRODUCTION}

It is known that biologically active materials formed by deposition of metal oxide nanostructures on the organic and polymeric systems surfaces reveal an ability to depress and kill pathogenic biological flora, and their introduction to organisms prevents "fixing" of viruses and bacteria to cell walls, improves antibacterial and antiviral immunity [1-3].
Here, very important is both the choice of inorganic material for modification of the biologically active materials surface and the deposition procedure.

Thin films or nanoscale coatings of $\mathrm{ZnO}$ nanoparticles on suitable substrates have excellent electrical, optical, and medical properties with broad range of applications for functional coatings, sensors, in optical devices, transparent electrodes, solar cells and antibacterial, antitumor activity [4-10].

Various methods like chemical, thermal, spray pyrolysis, pulsed laser deposition etc. have been developed to coat $\mathrm{ZnO}$ nanoparticles in the form of thin films on solid supports such as metal, metal oxides, glass or thermally stable substrates $[6,8,11-14]$.

Among the known methods of obtaining nanocompositions, magnetron deposition of metal oxide nanofilms on the organic and polymeric systems surfaces at relatively low temperatures holds a unique position. Stand-out distinguishing features of the method are ample opportunities for controlling the nanocomposition formation process, low deposition temperature $\left(20^{\circ} \mathrm{C} \leq \mathrm{T} \leq 100^{\circ} \mathrm{C}\right)$ and simplified technique of layer-by-layer deposition of coatings, allowing growth of nanocomposites with predetermined structural parameters.

Development of new nanotechnologies is of great importance for anticancer chemotherapy as the modern methods of anticancer drug administration in therapeutic (and slightly hither) doses are accompanied, as a rule, by development of serious side effects that frequently are the reasons of termination of the further course of treatment.

It is known that amino acid Schiff's bases form stable neutral lipophilic complexes with divalent ions of d-family metals. Some of them, for example, copper complexes reveal radioprotective, cytostatic action, inhibiting reversibly DNA synthesis [15-19]. It is also known that in organisms, basic amino acids are binding agents for metal oxides, in particular for $\mathrm{ZnO}$. Adjusting and immune effect of $\mathrm{ZnO}$ on DNA synthesis, produc- 
tion of interleukin (IL-2, IL-6, IL-10) and normalization of cytokine concentration was studied at the patients with chronic liver disease, in particular, hepatic cirrhosis [20].

On this basis, formation of thin films $\mathrm{ZnO}$ on the surfaces of biologically active compounds (aimed at the surface modification) by magnetron deposition of $\mathrm{Zn}$ target is of special interest.

This work is devoted to deposition of zinc oxide films on biologically active coatings and composite films of ethyl ether salicylidene DL-tyrosine, ethyl ether Salicylidene DL-tyrosine $\mathrm{Cu}$ (II) chelate with PVA aimed at modification of their surfaces and obtaining coatings and composite films with antitumor activity.

The paper discusses the following problems:

1) Obtaining of zinc oxide nanocomposites by deposition of zinc oxide nanofilms on coatings, composite films of ethyl ether salicylidene DL-tyrosine and ethyl ether salicylidene DL-tyrosine $\mathrm{Cu}$ (II) chelate by DCmagnetron deposition of zinc targets.

2) Study of anticancer activity of ethyl ether Salicylidene DL-tyrosine, ethyl ether salicylidene DL-tyrosine $\mathrm{Cu}$ (II) chelate and zinc oxide nanocomposites in the form of coatings and composite films

3) Structural, spectral properties of salicylidene amino acid and their chelate compounds, as well as $\mathrm{ZnO}$ nanocomposites coatings of $\mathrm{S} 1+\mathrm{ZnO}, \mathrm{S} 2+\mathrm{ZnO}$ and PVA composite films $(\mathrm{S} 1+\mathrm{PVA}+\mathrm{ZnO}, \mathrm{S} 2+\mathrm{PVA}+\mathrm{ZnO})$.

\section{EXPERIMENTAL DETAILS/ METHODOLOGY (SELECT THE MORE APPROPRIATE)}

The paper is aimed at obtaining of zinc oxide nanocomposite coatings and polymer composite films with anticancer activity by deposition of $\mathrm{ZnO}$ nanofilms on surfaces of ethyl ether salicylidene DL-tyrosine, S1 and their $\mathrm{Cu}$ (II) chelate, S2 by magnetron sputtering of $\mathrm{Zn}$ target. Ethyl ether salicylidene DL-tyrosine and ethyl ether salicylidene DL-tyrosine $\mathrm{Cu}$ (II) chelate are new compounds for the first time synthesized in the Institute of Fine Organic Chemistry of National Academy of Sciences of the Republic of Armenia. They were used as model compounds for obtaining zinc oxide nanocompositions.

\subsection{Formation of Coatings and Composite Films with PVA from Ethyl Ether Salicylidene DL-Tyrosine and Ethyl Ether Salicylidene DL-Tyrosine Cu (II) Chelate}

Coatings from ethyl ether salicylidene DL-tyrosine and ethyl ether salicylidene DL-tyrosine $\mathrm{Cu}$ (II) chelate were obtained on glass substrates as a paste with dimethyl sulfoxide.

As solvents, olive oil, ethylene glycol (EG), polyethylene glycol (PEG), dimethyl sulfoxide (DMSO) were tested. DMSO was chosen as a low-toxic substance with antiinflammatory, antimicrobial action, high permeability through biological membranes. Pastes from S1, S2 were prepared taking into account their daily maximum permissible doses for the animals.

Several samples of polyvinyl alcohol differed in molecular mass and functional composition were used to create needed polymeric matrix and choose the conditions of obtaining the films prospectively appropriate for their combination with S1,S2 and zinc oxide. The PVA samples were: PVA-1, MM approximately 20000, mass fraction of acetate group 1.3\%, PVA-2, MM approximately 21000 , mass fraction of acetate group $10.6 \%$, PVA-4, MM = 50000-60000, mass fraction of acetate group 5.3\%. PVA-4 differs from PVA-1 and PVA-2 in higher $\mathrm{MM}$, and its mass fraction of acetate group is intermediate between PVA-1 and PVA-2.

The composition films from S1 and S2 with PVA were obtained from $0.5 \mathrm{ml}$ of 5\% PVA solution with a measured amount of S1 and S2 corresponding to therapeutic doses of S1 and S2 for white nondescript mice. The film diameter was $2.8 \mathrm{~cm}$ (surface area was $6.1 \mathrm{~cm}^{2}$ ). On the composite films of S1 and S2 with PVA the $\mathrm{ZnO}$ nanofilms were deposited by magnetron sputtering of zinc target.

\subsection{DC-Magnetron Deposition of $\mathrm{ZnO}$ Nanofilms on Surfaces of Salicylidene Amino Acids and Their Chelates}

To deposit nanosize $\mathrm{ZnO}$ films on surfaces of coatings and composite films of ethyl ether salicylidene DL-tyrosine, ethyl ether salicylidene DL-tyrosine $\mathrm{Cu}$ (II) chelate, a modified UVN-71P3 device, DC-magnetron intended for sputtering of metal targets was used.

UVN-71P3 device was equipped with a system of working gas flow measurement and control consisting of supply and indication unit PR4000F as well as two gas flow regulators MFC 1179 for Ar and O2 gases.

The substrates from optic glass for deposition of coatings or composite films from the investigated compounds were fixed inside the device using special clamps ensuring their movement within the vacuum chamber. $\mathrm{ZnO}$ nanofilm deposition process was carried out by magnetron sputtering of $\mathrm{Zn}$ target at parallel arrangement of the target and substrate. The deposition device is powered from an energy supply source. To carry out experiments on $\mathrm{ZnO}$ nanofilm deposition within the investigated temperature interval, a system based on Peltier element or resistance heater ensuring decrease 
and stabilization of the substrate temperature was used. $\mathrm{ZnO}$ nanofilms were deposited on rotating substrates (to ensure uniform thickness) at the substrate temperature range from $20^{\circ} \mathrm{C}$ to $100^{\circ} \mathrm{C}$.

When selecting technological regimes of $\mathrm{ZnO}$ nanofilm deposition on the substrate (the working gases $\mathrm{O}_{2}$ and Ar ratio, operating current of the magnetron source, target-to-substrate distance, substrate temperature), the conditions were considered to eliminate undesirable extraneous transformations of salicylidene amino acids and their chelates.

To form zinc oxide nanocompositions of the investigated compounds S1, S2 in the form of coatings and composite films, a technique of $\mathrm{ZnO}$ nanofilm deposition on glass substrates was preliminary developed.

$\mathrm{ZnO}$ nanofilms were deposited on glass substrates by magnetron sputtering of $\mathrm{Zn}$ targets ( $55 \mathrm{~mm}$ in diameter) at the operating current from $80 \mathrm{~mA}$ to $500 \mathrm{~mA}$, pressure of $10^{-2} \mathrm{~mm} \mathrm{Hg}$, and target-to-substrate distance from 7 $\mathrm{cm}$ to $13 \mathrm{~cm}$. As working gases, $\mathrm{Ar}$ and $\mathrm{O}_{2}$ were used in the ratio of $70 \%-30 \%$. To keep clean the deposition process, the vacuum chamber was exhausted to $2 \times 10^{-6}$ $\mathrm{mm} \mathrm{Hg}$ before the film deposition.

\subsection{Technique of Identification of Antitumor Activity of Ethyl Ether Salicylidene DL-Tyrosine, Their Cu (II) Chelate and Zinc Oxide Nanocomposites on Strains of Inoculate Tumors}

The study was carried out in toxicology and chemotherapy laboratory of Scientific Technological Centre of Organic and Pharmaceutical Chemistry of the National Academy of Sciences of the Republic of Armenia under conditions close to GLP principles and European standards.

Antitumor coatings and composite films of zinc oxide nanocomposites of ethyl ether salicylidene DL-tyrosine, ethyl ether salicylidene DL-tyrosine $\mathrm{Cu}$ (II) chelate and initial compounds were tested on the strains of sarcoma 180 tumors inoculated to white nondescript mice. Preliminary, maximum permissible doses (MPD) were determined by vivisections, and on their basis-therapeutic doses of the substances, which made as a rule $20 \%$ of the single MPD.

For subinoculation, as a transplant the peaces of tumor tissues not subject to necrosis and crushed to homogeneous mass were used. Physiological salt solution was added to the tumor in 1:3-1:4 ratio, and the obtained suspension was introduced to the animals (with initial weight 22-26 g) subcutaneously by a syringe at a rate of $0.3 \mathrm{ml}$

Nanocomposites in the form of $\mathrm{ZnO}+(\mathrm{S} 1, \mathrm{~S} 2)$ coatings were introduced to the animals subcutaneously as a suspension in DMSO 48 hours after the tumor subinoculation on a daily basis during 6 days.

Zinc oxide nanocomposites and initial compounds in the form of composite films were deposited operationally in sterile conditions (box) by subcutaneous applications for 6 days through a 5-7 $\mathrm{mm}$ in section in spinal and scapular parts of the animals.

48 hours after the experiment the animals were killed, the tumors were withdrawn and weighed. Antitumor activity was determined by the percentage of the tumor inhibition with respect to the control animals.

\subsection{Characterization of Ethyl Ether Salicylidene DL-Tyrosine, Their Cu (II) Chelates and Zinc Oxide Nanocomposites}

X-ray diffraction (XRD) patterns were obtained on CAD4, Enraf-Nonius and DRON-2.0 X-ray diffractometers. NMR spectra were recorded on Varian Mercury 300VX spectrometer with all-round frequency $300 \mathrm{MHz}$.

IR spectra were recorded on NEXUS FT-IR spectrometer. Mass spectra were recorded on MX-1321A.

\section{RESULTS \& DISCUSSION}

\subsection{Selection of Optimum Surface Areas for S1, S2}

The $\mathrm{ZnO}$ nanofilm surface coatings are S1, S2 depositions over a certain surface area of object glass. Thickness and optimum $\mathrm{ZnO}$ nanofilm surface area was calculated for the case, when its content in the film was $5-10 \%$ of that of $\mathrm{S} 1, \mathrm{~S} 2$. It is known from publications that at addition of 5\% $\mathrm{ZnO}$ to plasma of rabbit with inculcated Staphylococcus, antibacterial activity increases in comparison with that for control samples without $\mathrm{ZnO}$ [20]. On this basis, $\mathrm{ZnO}$ content in the film (5-10\% of $\mathrm{S} 1$, S2 weight) was taken for rough estimate, with a view to obtain reliable optimum results. To ensure technological effectiveness of the deposition process, the surface area was calculated taking into account the amount of S1 and S2 for daily dose of 6 mice. Suspension of S1 + $\mathrm{ZnO}$ nanocomposite did not reveal reliable antitumor action $(10 \%)$ at subcutaneous introduction of $\mathrm{m}_{1}=1.4$ $\mathrm{mg} /$ mouse of ethyl ether salicylidene DL-tyrosine to mice, when $\mathrm{ZnO}$ deposition area on $\mathrm{S} 1$ was $\mathrm{s}_{1}=2.54$ $\mathrm{cm}^{2}$. However at the same daily dose, when $\mathrm{ZnO}$ deposition area on $\mathrm{S}_{1}$ coatings were $\mathrm{s}_{1}=9.62 \mathrm{~cm}^{2}$ and $\mathrm{s}_{2}=15.9$ $\mathrm{cm}^{2}$, antitumor activity was 30\%-32\% for $\mathrm{d}=100 \mathrm{~nm}$ thick $\mathrm{ZnO}$ nanofilms (Table 1).

At subcutaneous introduction of $\mathrm{S} 2+\mathrm{ZnO}$, when the content of ethyl ether salicylidene DL-tyrosine $\mathrm{Cu}$ (II) chelate was $\mathrm{m}=1.2 \mathrm{mg} /$ mouse and $\mathrm{s}=2.54 \mathrm{~cm}^{2}$, the 
antitumor effect was only $27 \%$. Taking into account the calculation for the $\mathrm{S} 1$ with optimum result, the $\mathrm{ZnO}$ nanofilm deposition area was calculated for $\mathrm{S} 2$ at the following daily doses: $\mathrm{m}_{1}=1.2 \mathrm{mg} /$ mouse, $\mathrm{m}_{2}=1.4$ $\mathrm{mg} / \mathrm{mouse} ; \mathrm{m}_{3}=2.8 \mathrm{mg} / \mathrm{mouse}$. The nanocomposites were formed on the following surface areas of ethyl ether salicylidene DL-tyrosine $\mathrm{Cu}$ (II) chelate:

$\mathrm{s}_{1}=9.62 \mathrm{~cm}^{2}, \mathrm{~s}_{2}=15.9 \mathrm{~cm}^{2}, \mathrm{~s}_{2^{*}}=19.8 \mathrm{~cm}^{2}, \mathrm{~s}_{3}=31.8$

$\mathrm{cm}^{2}$. Chemotherapeutic investigations have revealed increase in antitumor activity from $27 \%$ to $42 \%$ at daily dose $\mathrm{m}_{1}=1.2 \mathrm{mg} / \mathrm{mouse}$. However with further increase of $\mathrm{ZnO}$ nanofilm surface area, a slight decrease of activity takes place. At the increase of daily dose to $\mathrm{m}=2.8$ $\mathrm{mg} / \mathrm{mouse}$ and selection of optimum area, $\mathrm{s}=31.8 \mathrm{~cm}^{2}$, increase in antitumor activity to $47 \%$ was revealed (Table 1).

Optimum $\mathrm{ZnO}$ nanofilm area coated by ethyl ether salicylidene DL-tyrosine and ethyl ether salicylidene DL-tyrosine $\mathrm{Cu}$ (II) chelate was determined. Significant increase in antitumor activity of $\mathrm{ZnO}$ nanocomposites of ethyl ether salicylidene DL-tyrosine $\mathrm{Cu}$ (II) chelate in comparison with the initial compound is observed. It was revealed that $\mathrm{ZnO}$ quantitative content in nanofilms makes $10 \%$ of therapeutic dose of the initial compounds.

\subsection{Variation of Structural Characteristics of PVA in Composite Films with S1, S2}

It was revealed at formation of composite films PVA with $\mathrm{S} 1$ and $\mathrm{S} 2$ that the films obtained from the mixture of PVA-1 and S-1 did not dissolve in water after drying; the films obtained from the mixture of PVA-2 and S-1 (as well as PVA-2 and S-2) dissolve in water; PVA-1 film did not dissolve in water after deposition of $\mathrm{ZnO}$ nanofilms (by magnetron sputtering of $\mathrm{Zn}$ target) on its surface, whereas PVA-2 film with $\mathrm{ZnO}$ did dissolve.

Solubility of the films before and after deposition of $\mathrm{ZnO}$ nanofilms was studied both in model conditions at various $\mathrm{pH}$ and in vivo by subcutaneous introduction to mice and measurement of solubility time.

The following results were obtained: (PVA-1 $+\mathrm{ZnO}$ ) film did dissolve in animal organisms, but slowly, during 4 days. However (PVA-1 $+\mathrm{S} 1+\mathrm{ZnO}$ ) film resolved under the animal skin in 6-7 days (Table 2), i.e. its prolonged dissolution in animal organisms was ensured.

(PVA-1 + S2 + ZnO) film did dissolve under the mice skin.

(PVA-2 + S1) and (PVA-2 + S1 + ZnO) films did dissolve 4-5 days, no antitumor effect was revealed.

(PVA-2 + S2) and (PVA-2 + S2 + ZnO) films did dissolve in one day, however (PVA-4 + S2) and (PVA-4 + $\mathrm{S} 2+\mathrm{ZnO}$ ) resolved under the animal skin in 5-6 days (Table 2).

So, it was revealed that for ethyl ether salicylidene
Table 1. Effect of $\mathrm{ZnO}$ nanofilm area surface on antitumor activity of $\mathrm{ZnO}$ nanocomposites.

\begin{tabular}{cccc}
\hline Composition & $\begin{array}{c}\text { Daily dose, } \\
\text { mglmouse }\end{array}$ & $\begin{array}{c}\text { Coated area (S1,S2) of } \\
\text { glass substrates, cm } \\
\text { (daily dose for 6 mice) }\end{array}$ & $\begin{array}{c}\text { Antitumor } \\
\text { action, \% }\end{array}$ \\
\hline S1 & 1.4 & - & 31 \\
$\mathrm{~S} 1+\mathrm{ZnO}$ & 1.4 & 2.54 & 10 \\
$\mathrm{~S} 1+\mathrm{ZnO}$ & 1.4 & 9.62 & 30 \\
$\mathrm{~S} 1+\mathrm{ZnO}$ & 1.4 & 15.90 & 33 \\
S2 & 1.4 & - & 18 \\
$\mathbf{S 2}$ & 2.8 & - & 20 \\
$\mathrm{~S} 2+\mathrm{ZnO}$ & 1.2 & 2.54 & 27 \\
$\mathrm{~S} 2+\mathrm{ZnO}$ & 1.2 & 9.62 & 42 \\
$\mathrm{~S} 2+\mathrm{ZnO}$ & 1.4 & 15.9 & 42 \\
$\mathrm{~S} 2+\mathrm{ZnO}$ & 1.4 & 19.8 & 40 \\
$\mathrm{~S} 2+\mathrm{ZnO}$ & 2.8 & 31.8 & 47 \\
\hline
\end{tabular}

Table 2. Effect of polymer grade on in vivo solubility and antitumor activity of $\mathrm{ZnO}$ nanocomposite films.

\begin{tabular}{cccc}
\hline Composition & $\begin{array}{c}\text { Daily dose, } \\
\text { mglmouse }\end{array}$ & $\begin{array}{c}\text { In vivo solubility of } \\
\text { films under the mice } \\
\text { skin }\end{array}$ & $\begin{array}{c}\text { Antitumor } \\
\text { action, \% }\end{array}$ \\
\hline S1 & 1.4 & - & 31 \\
$\mathrm{~S} 1+$ PVA-1 + ZnO & 1.4 & Dissolved, 6-7 days & 31 \\
$\mathrm{~S} 1+$ PVA-2 + ZnO & 1.4 & Dissolved, 4-5 days & No effect \\
$\mathrm{S} 1+$ PVA-4 + ZnO & 1.4 & Dissolved, 5-6 days & No effect \\
S2 & 1.4 & - & 18 \\
S2 & 2.8 & - & 20 \\
$\mathrm{~S} 2+$ PVA-1 + ZnO & 1.4 & Not dissolved & - \\
$\mathrm{S} 2+$ PVA-2 + ZnO & 1.4 & Dissolved, 4-5 days & 24 \\
$\mathrm{~S} 2+$ PVA-4 + ZnO & 1.4 & Dissolved, 5-6 days & 42 \\
$\mathrm{~S} 2+$ PVA-4 + ZnO & 2.8 & Dissolved, 5-6 days & 48 \\
\hline
\end{tabular}

DL-tyrosine the most optimum option of the composite film formation is the use of PVA-1 with molecular weight 20000 , mass fraction of acetate group $1.3 \%$. To form the composite film with ethyl ether salicylidene DL-tyrosine $\mathrm{Cu}$ (II) chelate, as an intermediate option PVA-4 was selected with molecular weight 60000 , where the amount of acetate groups $(5.7 \%)$ is intermediate between PVA-1 (1.3\%) and PVA-2 (10,5\%) and molecular weight is higher. 


\subsection{Optimum Technological Parameters of ZnO Nanofilm Deposition on Coatings and S1, S2 Composite Films}

Optimum technological parameters of zinc oxide nanofilm magnetron deposition on the surface of ethyl ether salicylidene DL-tyrosine, ethyl ether salicylidene DLtyrosine $\mathrm{Cu}$ (II) chelate in the form of coatings (S1, S2) and composite films (PVA + S1, PVA + S2) were determined.

The substrate material temperature was measured depending on the changes of the magnetron source operating current at various target-to-substrate distances (Figure 1(a)). It follows from this dependence that within the investigated range of operating currents from $80 \mathrm{~mA}$ to $500 \mathrm{~mA}$, the substrate surface temperature was below $100^{\circ} \mathrm{C}$. At such temperatures, there were no undesirable extraneous transformations of the surface of biologically active substances S1 and S2. X-ray investigations were carried out and experimental results on antitumor activeity were obtained for $\mathrm{ZnO}$ compositions formed at various technological regimes of $\mathrm{ZnO}$ deposition on the researched biologically active compounds. It was revealed that the structure of $100 \mathrm{~nm}$ thick $\mathrm{ZnO}$ nanofilms with optimum size of nanoparticles $(15-30 \mathrm{~nm})$ is appropriate for interaction with the researched biologically active compounds in form of both coatings and composite films. Such nanosize $\mathrm{ZnO}$ films were obtained at the following technological regimes: operating current from $400 \mathrm{~mA}$, operating voltage $240 \mathrm{~V}$ and operating pressure $10^{-2} \mathrm{~mm}$ $\mathrm{Hg}$. For these regimes, the $\mathrm{ZnO}$ nanofilm deposition rate was studied depending on target-to-substrate distance (Figure 1(b)). Optimum target-to-substrate distance, 10 $\mathrm{cm}$ was selected taking into account the obtained dependences and uniformity of the $\mathrm{ZnO}$ films deposited on the S1, S2 sample surfaces. At such target-to-substrate distance the film growth rate made approximately 6 $\mathrm{nm} / \mathrm{min}$.

Composites on the basis of $\mathrm{ZnO}$ nanofilms and biologically active substances S1 and S2 were obtained by deposition of approximately $100 \mathrm{~nm}$ thick zinc oxide nanofilm (using Zn target) on S1 and S2 deposited in the form of coatings or composite films, in the following technological regime: operating current from $400 \mathrm{~mA}$, gas mixture $\mathrm{Ar}$ and $\mathrm{O}_{2}$ at 70:30 ratio; operating pressure $10^{-2} \mathrm{~mm} \mathrm{Hg}$, target-to-substrate distance $10 \mathrm{~cm}$.

\subsection{Antitumor Activity of $\mathrm{S} 1, \mathrm{~S} 2$ and Zinc Oxide Nanocomposites}

It was revealed as a result of study of acute toxicity that MPD values for S1 and S2 are $50 \mathrm{mg} / \mathrm{kg}$ and 250 $\mathrm{mg} / \mathrm{kg}$, correspondingly. In view of these data, as preliminary therapeutic dose for S1 and S2 were used 15

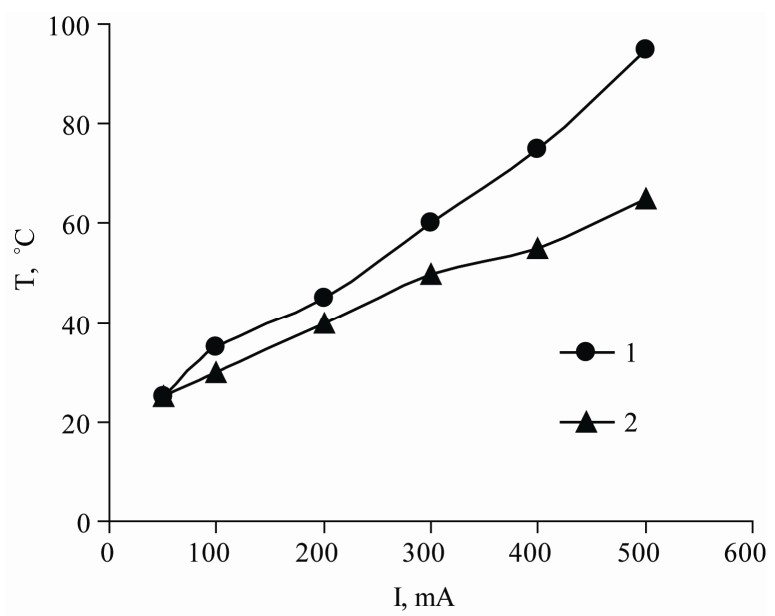

(a)

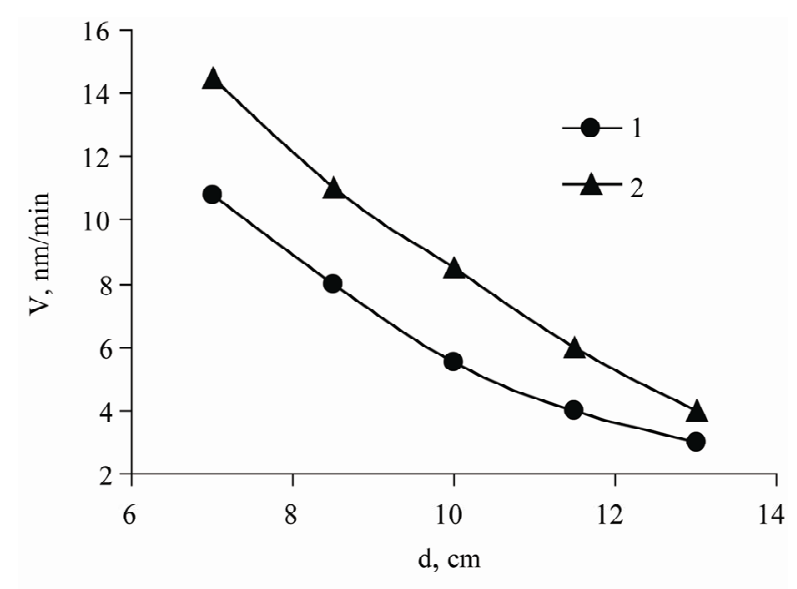

(b)

Figure 1. (a) Dependence of the substrate material temperature upon the magnetron source current at various target-to-substrate distances: 1) $7 \mathrm{~cm}$; 2) $10 \mathrm{~cm}$; (b) Dependence of $\mathrm{ZnO}$ nanofilm deposition rate upon the target-to-substrate distances at various magnetron source currents: 1) $200 \mathrm{~mA}$; 2) $400 \mathrm{~mA}$.

$\mathrm{mg} / \mathrm{kg}$ and $50 \mathrm{mg} / \mathrm{kg}$, correspondingly.

In chemotherapeutic experiments $\mathrm{S} 1$ at $0.3 \mathrm{mg} /$ mouse $(15 \mathrm{mg} / \mathrm{kg})$ dose did not reveal antitumor effect and general toxic action, so in subsequent experiment the dose was increased to $1.5 \mathrm{mg} /$ mouse. It was revealed that at such dose $\mathrm{S}_{1}$ inhibited sarcoma 180 growth by $31 \%$ and did not reveal toxic action on the animal organism. S2 at therapeutic dose of $1 \mathrm{mg} / \mathrm{mouse}$ did not cause significant inhibition of sarcoma 180 (18\%), and with the dose increase to $2.8 \mathrm{mg} / \mathrm{mouse}$ no increase in therapeutic action was determined (20\%).

$\mathrm{S} 1+\mathrm{ZnO}$ nanocomposite in the form of coatings and composite films S1 + PVA-1 + $\mathrm{ZnO}$ revealed the same activity as $\mathrm{S} 1: 33 \%$ and $31 \%$. However $\mathrm{S} 2+\mathrm{ZnO}$ nanocomposites where S2 content was 1 or $2.8 \mathrm{mg} /$ mouse, revealed at subcutaneous injection to animals and film 
application much higher antitumor activity (in form of both $\mathrm{S} 2+\mathrm{ZnO}$ coating, 47\%, and $\mathrm{S} 2+$ PVA-4 $+\mathrm{ZnO}$ composite films, $48 \%)$ than $\mathrm{S} 2(20 \%)$.

So, as distinct from nanocomposites with $\mathrm{S} 1+\mathrm{ZnO}$, $\mathrm{S} 2+\mathrm{ZnO}$ in form of both coatings and composite films revealed relatively higher therapeutic effectiveness than at using S2 only.

\subsection{Structural, Spectral Characteristics of S1, S2 and Zinc Oxide Nanocomposites}

Complete X-ray diffraction study of ethyl ether Salicylidene DL-tyrosine was carried out using CAD4, Enraf-Nonius diffractometer. The compound was synthesized for the first time in the Institute of Fine Organic Chemistry of National Academy of Sciences of the Republic of Armenia.

Figure 2 present the molecular structure (Figure 2(a)) and crystal packing on plane ac for three molecules (for cleanness) (Figure 2(b)) of ethyl ether salicylidene DL-tyrosine. In the compound's crystalline structure,

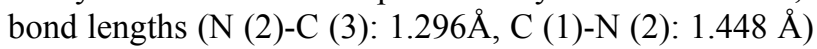
are typical for $\mathrm{C}=\mathrm{N}$ Schiff base bond and $\mathrm{C}-\mathrm{N}$ single bond, respectively [21]. The compound structure contains intramolecular hydrogen bonds between $\mathrm{N}(2)$ and $\mathrm{O}(10)$ atoms, $\mathrm{N}(2)-\mathrm{H}(2) \ldots \mathrm{O}(10), 2.565 \AA$ in length and intermolecular hydrogen bonds $\mathrm{O}(18)-\mathrm{H}(18) \ldots \mathrm{O}$ (10), $2.623 \AA$ in length.

IR study was carried out on ethyl ether salicylidene DL-tyrosine $\mathrm{Cu}$ (II) chelate and has shown that the compound includes free hydroxyl group of a salicylidene fragment in the valence vibration region $3309 \mathrm{~cm}^{-1}$.

In the metal complex, shift of $\mathrm{COO}^{-}$absorption band was occurred to $1668 \mathrm{~cm}^{-1}$ as distinct from S1 with 1733 $\mathrm{cm}^{-1}$, and a shift $-\mathrm{CH}=\mathrm{N}$ to $1651 \mathrm{~cm}^{-1}$ due to interacttion between $\mathrm{Cu}$ and nitrogen on account of free electron pair.

Also, there were differences in the region of deformation vibrations: C-O, C-O-H and C-O-C, Me-O, Me-N.

Also, IR study was carried out on ethyl ether Salicylidene DL-tyrosine zinc oxide nanocomposites. The study has revealed identity of ethyl ether salicylidene DL-tyrosine zinc oxide nanocomposite and initial S1 spectra. They did not contain expected shifts of absorption bands of $\mathrm{C}=\mathrm{O}, \mathrm{C}-\mathrm{O}-\mathrm{H}, \mathrm{C}-\mathrm{O}-\mathrm{C}$ functional groups in $1206-1065 \mathrm{~cm}^{-1}$ region (deformation vibrations) and in the valence vibration region of $\mathrm{OH}$ group (3000-3500 $\left.\mathrm{cm}^{-1}\right)$. $\mathrm{ZnO}$ presumably presents in the form of mechanical mixture with ethyl ether salicylidene DL-tyrosine.

Comparison of the absorption spectra of metal complex and ethyl ether salicylidene DL-tyrosine $\mathrm{Cu}$ (II) chelate zinc oxide nanocomposite has revealed a shift of absorption band in the valence vibration region of $\mathrm{OH}$ group from $3309 \mathrm{~cm}^{-1}$ in the initial metal complex to

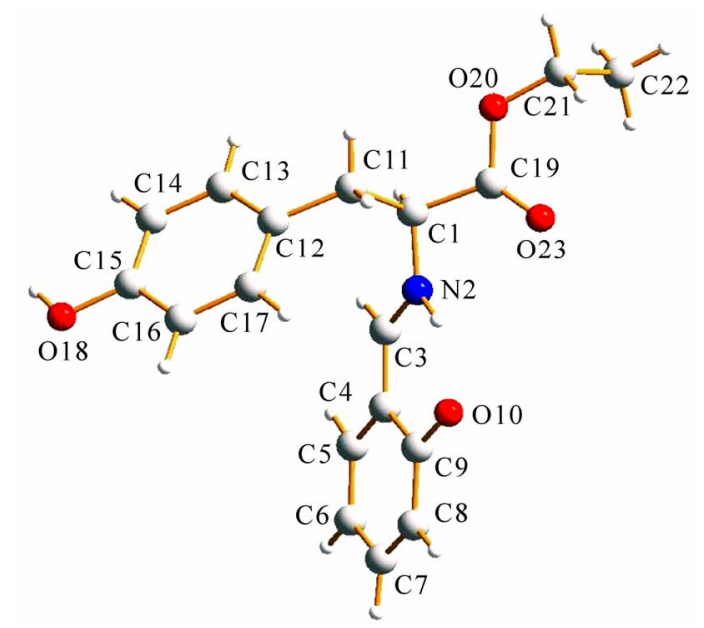

(a)

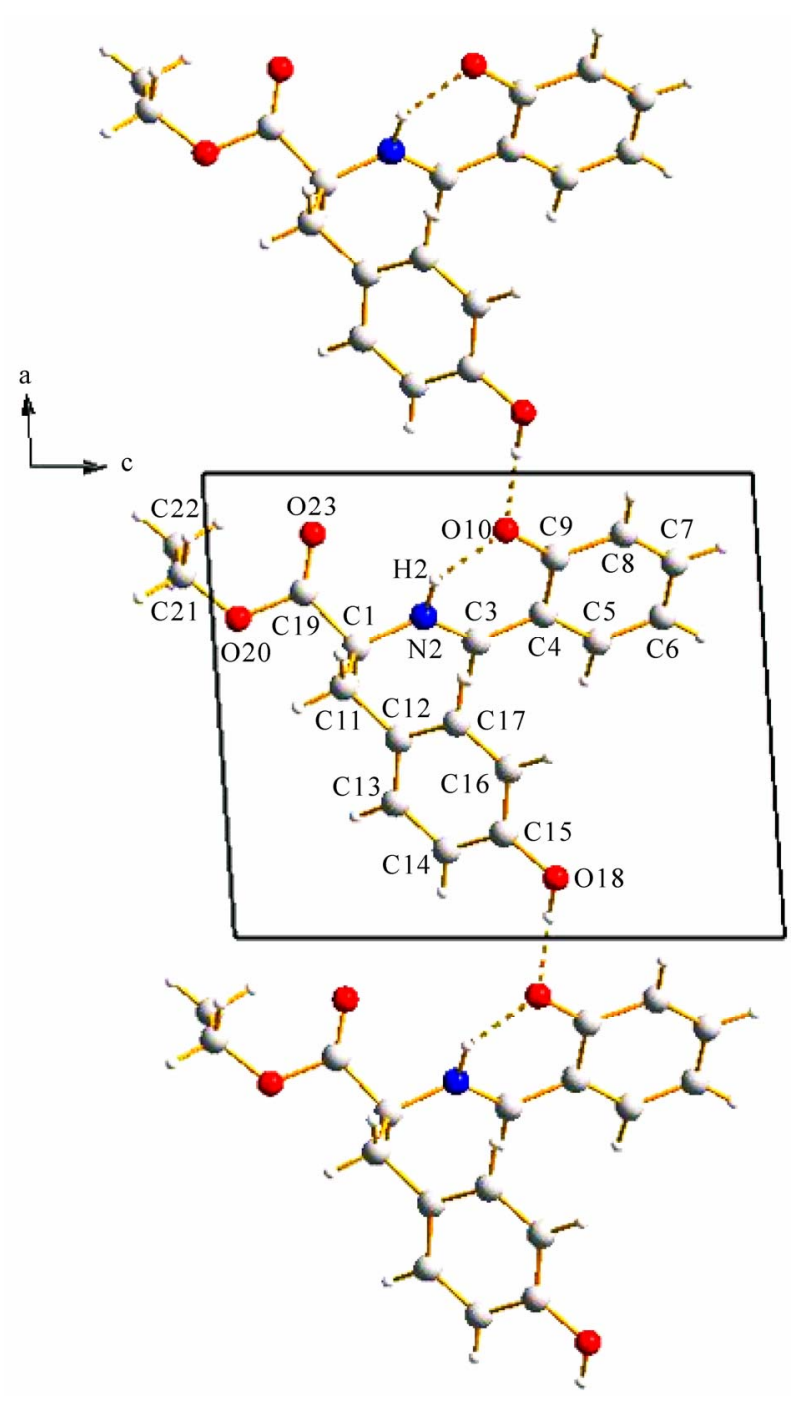

(b)

Figure 2. Molecular structure (a) and crystal packing on the plane ac (b) of ethyl ether salicylidene DL-tyrosine. 
$3335 \mathrm{~cm}^{-1}$ in metal oxide composite. It is likely that this shift is related to interaction between $\mathrm{ZnO}$ and $\mathrm{OH}$ group of the salicylidene fragment.

In case of $\mathrm{ZnO}$ nanocomposite films ( $\mathrm{S} 1+$ PVA-1 + $\mathrm{ZnO})$ there is interaction of PVA-1 functional groups with $\mathrm{ZnO}$ and absence of $\mathrm{ZnO}-\mathrm{S} 1$ interaction. In case of $(\mathrm{S} 2+\mathrm{PVA}-4+\mathrm{ZnO})$ films interactions of $\mathrm{ZnO}$ with functional groups of both PVA-4 and S2 were revealed.

Study of nanocomposite films has revealed the dependence of the interactions with formation of bonds in the composite film components upon the structure of S1 and S2 compounds.

$\mathrm{X}$-ray investigations of ethyl ether salicylidene DLtyrosine have detected presence of intramolecular hydrogen bond $\mathrm{N}-\mathrm{H} . . \mathrm{O}$ and intermolecular hydrogen bonds of $\mathrm{OH}$ hydroxyl group and carbonyl group, which form chains in compounds. IR spectral investigations of $\mathrm{ZnO}$ nanocomposite coatings $(\mathrm{S} 1+\mathrm{ZnO})$ did not reveal $\mathrm{ZnO}-\mathrm{S} 1$ bonds. Spectral investigations of $\mathrm{ZnO}$ nanocomposite films ( $\mathrm{S} 1+\mathrm{PVA}+\mathrm{ZnO})$ have revealed interaction of PVA functional groups with $\mathrm{ZnO}$ and absence of $\mathrm{ZnO}-\mathrm{S} 1$ interaction. IR spectral investigations of ethyl ether salicylidene DL-tyrosine $\mathrm{Cu}$ (II) chelate did not reveal intramolecular or intermolecular hydrogen bonds in the structure; however $\mathrm{ZnO}$ nanocomposite coatings, $\mathrm{S} 2+\mathrm{ZnO}$, reveal obvious formation of intermolecular hydrogen bond of $\mathrm{ZnO}$...HO type. $\mathrm{ZnO}$ nanocomposite films from PVA with $\mathrm{S} 2$ reveal interaction of $\mathrm{ZnO}$ with functional groups of both PVA and S2.

Thus, the surface modification of ethyl ether Salicylidene DL-tyrosine $\mathrm{Cu}$ (II) chelate coatings as well of composite films from these compounds by deposition of $\mathrm{ZnO}$ nanofilms using magnetron sputtering results in increase of antitumoral activity of the obtained nanocomposites, apparently due to formation of intermolecular hydrogen bond between $\mathrm{ZnO}$ and hydroxyl groups of these compounds.

\section{CONCLUSIONS}

1) Zinc oxide nanocomposites of ethyl ether salicylidene DL-tyrosine and ethyl ether salicylidene DL-tyrosine $\mathrm{Cu}$ (II) chelate were obtained by deposition of approximately $100 \mathrm{~nm}$ thick zinc oxide nanofilms on coatings and composite S1, S2 films using magnetron sputtering of $\mathrm{Zn}$ targets in the temperature range of $20^{\circ} \mathrm{C} \leq \mathrm{T} \leq$ $100^{\circ} \mathrm{C}$ at operating pressure of $10^{-2} \mathrm{~mm} \mathrm{Hg}$.

2) Optimum $\mathrm{ZnO}$ nanofilm area coated by ethyl ether salicylidene DL-tyrosine and ethyl ether salicylidene DL-tyrosine $\mathrm{Cu}$ (II) chelate was determined. Significant increase in antitumor activity of $\mathrm{ZnO}$ nanocomposites of ethyl ether salicylidene DL-tyrosine $\mathrm{Cu}$ (II) chelate in comparison with the initial compound is observed. It was revealed that $\mathrm{ZnO}$ quantitative content in nanofilms makes $10 \%$ of therapeutic dose of the initial compounds.

3) Zinc oxide composite films of ethyl ether salicylidene DL-tyrosine and ethyl ether salicylidene DL-tyrosine $\mathrm{Cu}$ (II) chelate with polyvinyl alcohol are obtained ensuring their prolongation in animals (mice) organizm. It is shown that for ethyl ether salicylidene DL-tyrosine the most optimum option of the composite film formation is the use of PVA with molecular weight 20000 and mass fraction of acetate group $1.3 \%$ To form the composite film with ethyl ether salicylidene DL-tyrosine $\mathrm{Cu}$ (II) chelate, the optimum option is PVA with molecular weight 60000 and amount of acetate groups of $5.7 \%$.

4) Chemotherapeutic investigations have shown that antitumor activity of zinc oxide nanocomposites of ethyl ether salicylidene DL-tyrosine in the form of both $\mathrm{S} 1+$ $\mathrm{ZnO}$ coatings $(33 \%)$ and $\mathrm{S} 1+\Pi \mathrm{\Pi BC}+\mathrm{ZnO}$ composite films $(31 \%)$ was approximately the same as that of $\mathrm{S} 1(31 \%)$.

5) $\mathrm{ZnO}$ nanocomposites with $\mathrm{Cu}$ (II) chelate of ethyl ether salicylidene DL-tyrosine (as distinct from their ester) in the form of $\mathrm{S} 2+\mathrm{ZnO}(47 \%)$ coatings and $\mathrm{S} 2+$ $\mathrm{PVA}+\mathrm{ZnO}$ (48\%) composite films have revealed considerable increase in antitumoral activity in comparison with S2 (20\%).

6) X-ray investigations of ethyl ether salicylidene DL-tyrosine have detected presence of intramolecular hydrogen bonds and intermolecular hydrogen bonds, which form chains in the compounds. IR spectral investtigations of $\mathrm{ZnO}$ nanocomposite coatings $(\mathrm{S} 1+\mathrm{ZnO})$ did not reveal $\mathrm{ZnO}-\mathrm{S} 1$ bonds. Spectral investigations of $\mathrm{ZnO}$ nanocomposite films ( $\mathrm{S} 1+\mathrm{PVA}+\mathrm{ZnO})$ have revealed interaction of PVA functional groups with $\mathrm{ZnO}$ and absence of $\mathrm{ZnO}-\mathrm{S} 1$ interaction.

7) IR spectral investigations of ethyl ether salicylidene DL-tyrosine $\mathrm{Cu}$ (II) chelate did not reveal intramolecular or intermolecular hydrogen bonds in the structure, however $\mathrm{ZnO}$ nanocomposite coatings, $\mathrm{S} 2+\mathrm{ZnO}$, reveal (judging from the deviation in valence vibrations of $\mathrm{OH}$ group) obvious formation of intermolecular hydrogen bond of $\mathrm{ZnO}-\mathrm{H}$... O type. $\mathrm{ZnO}$ nanocomposite films from PVA with $\mathrm{S} 2$ reveal interaction of $\mathrm{ZnO}$ with functional groups of both PVA and S2.

8) Surface modification of ethyl ether salicylidene DL-tyrosine $\mathrm{Cu}$ (II) chelate coatings as well as composite films based on these compounds, by deposition of $\mathrm{ZnO}$ nanofilms using magnetron sputtering resilts in increase of antitumor activity of the obtained nanocomposites, apparently due to formation of intermolecular hydrogen bonds between $\mathrm{ZnO}$ and hydroxyl groups of these compounds.

\section{ACKNOWLEDGEMENTS}

This work was supported by Grant A-1563 awarded by the Interna- 
tional Science and Technology Center.

\section{REFERENCES}

[1] Brown, S. (1992) Engineered iron oxide-adhesion mutants of the Escherichia coli phage lambda receptor. Proceedings of the National Academy of Sciences, USA, 1992, 89, 8651-8655.

[2] Burrell, R.E. (1997) Anti-microbial coating for medical devices. Patent Application, 1203.

[3] Chule, K., Chule, A.V., Chen, B.-J. and Ling, Y.-C. (2006) Preparation and characterization of $\mathrm{ZnO}$ nanoparticles coated paper and its antibacterial activity study. Green Chemistry, 8, 1034-1041.

[4] Wang, Z.L. (2004) Zinc oxide nanostructures: growth, properties and applications. Journal of Physics: Condensed Matter, 16, 829.

[5] Wang, X.D., Summers, C.J. and Wang, Z.L. (2004) Large-scale hexagonal-patterned growth of aligned $\mathrm{ZnO}$ nanorods for nano-optoelectronics and nanosensor arrays. Nano Letters, 4, 423.

[6] Shim, E.S., Kang, H.S., Kang, J.S., Kim, J.H. and Lee, S. Y. (2002) Effect of the variation of film thickness on the structural and optical properties of $\mathrm{ZnO}$ thin films deposited on sapphire substrate using PLD. Applied Surface Science, 186, 474-476.

[7] Chen, P., Ma, X. and Yang, D., (2006) Fairly pure ultraviolet electroluminescence from $\mathrm{ZnO}$-based light-emitting devices. Applied Physics Letters. Applied Physics Letters, 89, 111-112.

[8] Jin, B.J., Woo, H.S., Im, S., Base, S.H. and Lee, S.Y. (2001) Applied Surface Science, 169-170, 521-524.

[9] Hill, G.M., Mahan, D.C., Carter, S.D., Cromwell, G.L., Ewan, R.C., Harrold, R.L., Lewis, A.J., Miller, P.S., Shurson, G.C. and Veum, T.L. (2001) Effect of pharmacological concentrations of zinc oxide with or without the inclusion of an antibacterial agent on nursery pig performance. Journal of Animal Science, 79, 34-41.

[10] Hanley, C., Layne J., Punnoose, A., Reddy K.M., Isaac C., Andrew C., Kevin F. and Denise W. (2008) Increase in Concentration of a Zn-Containing Volatile Complex by UV Irradiation of a Target for ZnO Films Synthesis. Nanotechnology, 19, 10.

[11] Arakelova, E., Grigoryan F., Parvanyan, V., Asatryan, G. and Antonio, S. (2006) Increase in concentration of a Zn-containing volatile complex by UV irradiation of a target for $\mathrm{ZnO}$ films synthesis. Texas. EPD Congress 2006, Texas, 2006, 813-818.

[12] Arakelova, E., Parvanyan, F.G.V., Asatryan, G. and Anto- nio, S. (2006) Study of decomposition regularities for a $\mathrm{Zn}$-containing volatile complex used in $\mathrm{ZnO}$ films synthesis. Texas EPD Congress 2006, Texas, 2006, 883-888.

[13] Xu, W.Z., Ye, Z.Z., Zeng, Y.J., Zhu, L.P., Zhao, B.H., Jiang, L., et al., (2006) ZnO light-emitting diode grown by plasma-assisted metal organic chemical vapor deposition. Applied Physics Letters, 88, 112-116.

[14] Banerjee, A.N., Ghosh, C.K., Chattopadhyay, K.K., Minoura, H., Sarkar, A.K., Akiba, A. and Kamiya, A. (2006) Low-temperature deposition of $\mathrm{ZnO}$ thin films on PET and glass substrates by DC-sputtering technique. Thin Solid Films, 496, 112-116.

[15] Ghazaryan, S.H., Grigoryan, K.P., Ghevondyan, A.I., Minasyan, S.H., Tonoyan, V.C., Bajinyan, S.A., Poghosyan A.S., Malakyan, M.H. and Sorensen, J. R. S. (2001) The synthesis of new derivatives of amino acids and peptides: Study of the radioprotective activity. 14th. International Conference on Radiopharmaceutical Chemistry, Switzerland, 2001, 10-15.

[16] Minasyan, S.H., Ghazaryan, S.H., Tonoyan, V.C., Bajinyan, S.A., Grigoryan, K.P., Sorensen, J.R.S. and Greenaway F.T. (2006) Synthesis, characterization, and measurement of antioxidant reactivity of SalicylideneD,L-Tyrosine Ethyl Ester and Copper (II)(Salicylidene-D, LTyrosine Ethyl Ester)2 in a linoleic acid peroxidation reaction system. Synthesis and Reactivity in Inorganic, Metal-Organic, and Nano-Metal Chemistry, 36, 425-434.

[17] Parashar, R.K., Sharma, R.C. and Mohab, G. (1987) Synthesis and biological activity of some copper tridentate Schiff Buses. In: Sorenson J.R.J. Ed., Biology of copper complexes. Humana Press, Clifton NJ, 533-540.

[18] Nath, M., Kamaluddin, L. and Cheema, J. (1993) Copper (II) complexes of salicylidene amino acid Schiff bases as models. Peroxidase and catalase. Indian Journal of Chemistry, 32, 108-113.

[19] Picart, L., Goodwin, W.H., Murphy, T.B. and Johnson D.K. (1982) Zinc regulates DNA synthesis and IL-2, IL-6, and IL-10 production of PWM-stimulated PBMC and normalizes the periphere cytokine concentration in chronic liver disease. Journal of Cell Biochemistry, 6, 172-173.

[20] Akiyama, H., Yamasaki, O. Kanzaki, H., Tada, J. and Arata, J. (1998) Effect of zinc oxide on the attachment of Staphylococcus aureus strains. Journal of Dermatological Science, 17, 67-74.

[21] Zhou, G.D. and Duan L.Y. (1995) Basis of structural chemistry. 2nd Edition, Perking University Publishing Corporation, Beijing, 249-250. 